\title{
Pengaruh Informasi Akuntansi Keuangan Perusahaan Terhadap Harga Saham Pada Perusahaan-Perusahaan Industri Perdagangan, Jasa Dan Investasi Yang Terdaftar di Bursa Efek Indonesia Untuk Tahun 2008 Hingga 2016
}

\author{
DINI ONASIS \\ Universitas Lancang Kuning \\ Jln. Yos Sudarso KM 08 Rumbai Telp. (061) 52581 \\ E-mail : dinionasis@unilak.ac.id
}

\begin{abstract}
The purpose of establishing a company is to gain the maximum profit. The next goal is to prosper shareholder value. One of the tools that a company uses to achieve its objectives is financial accounting called Financial statements. The financial statements also indicate what management has done (stewardship), or Management's accountability of the resources entrusted to it. Users of financial statements want to assess what has been done by management or accountability what management does to the resources entrusted to it. Accounting information from the financial statements can describe the condition of the company. In this study examine the market reaction of information received by the public (Investor) on stock prices. If the information presented reports success in performance then the market will respond positively and if the performance fails then the market will respond negatively with the company's stock price decline presented. Researchers examine the influence of information revealed by the company on its Financial Statement to their share price, where the information used as a variable is Stock Price, Net Profit (Net Profit), Liabilities, Capital, Sales, EBT and Size Asset). The data used is a period of 9 years, long time data is to be able to find better results of research than a period of only a few years. The findings of this study, Variable Liabilities have a significant effect on stock prices, Variable Capital has no significant effect on stock prices, Variable Sale significant effect on stock prices, EBT variables have a significant effect on stock prices, Profit variables have no significant effect on stock prices.
\end{abstract}

Keywords: Liabilities, Sale, Capital, EBT, Profit, Stock Price

Sebagaimana dijelaskan oleh Palepu dan Healy (2014) bahwa investor menggunakan data Laporan Keuangan untuk melakukan analisis bisnis harus menyadari bahwa Pelaporan Keuangan dipengaruhi oleh aktivitas bisnis perusahaan dan Sistem Akuntansi, dan aspek kunci dalam analisis Laporan Keuangan adalah pemahaman mengenai pengaruh sistem akuntansi terhadap kualitas data Laporan Keuangan yang akan digunakan dalam analisis.

Oleh sebab itu, manajemen ikut berperan dalam gambaran faktor-faktor fundamental dan Kinerja Keuangan yang berupa angka-angka yang disusun dan disajikan dalam Laporan Keuangan oleh manajemen, maka lahirlah penelitian ini, yang membawa unsur Novelty, yaitu mengkaji pengaruh angka-angka pada Laporan Keuangan terhadap harga saham.

Pada penelitian ini mengkaji reaksi pasar atas informasi yang diterima publik (Investor) atas harga saham. Jika informasi yang disajikan melaporkan keberhasilan didalam kinerja maka pasar akan merespon positif dan jika kegagalan kinerja maka pasar akan merespon negative dengan dipresentasikan turunnya harga saham perusahaan tersebut.

Penelitiannya Triyono dan Hartono (2000) dengan beberapa perbedaan berikut. Penelitian ini menggunakan laba (Profit) karena informasi laba mempunyai kandungan informasi yang direaksi oleh investor dan mampu menggambarkan hubungan laba dengan harga saham. Febrianto dan Widiastuty (2005) menguji 
diantara tiga laba akuntansi (laba kotor, laba operasi dan laba bersih) mana yang lebih bermakna bagi investor. Penelitinya membuktikan bahwa angka laba kotor lebih mampu memberikan gambaran yang lebih baik tentang hubungan laba dengan harga saham dibandingkan dua laba lainnya. Zain (2007) yang juga menguji tiga laba akuntansi. Penelitiannya berhasil membuktikan bahwa laba kotor berpengaruh dominan terhadap pengambilan keputusan investor.

Miller dan Rock (1985) dalam Daniati (2006) dengan signaling theory menjelaskan bahwa pasar bereaksi negative terhadap pengumuman pendanaan dari kas. Hal ini akan berpenagruh terhadap arus kas operasi yang lebih rendah untuk masa yang akan datang. Selain itu juga berpengaruh terhadap perubahan deviden yang sangat erat hubungannya dengan return saham.

Adapun Tujuan penelitian adalah :

1. Untuk Mengkaji dan menganalisis Pengaruh Net Profit (Laba Bersih) terhadap Harga Saham.

2. Untuk Mengkaji dan menganalisis pengaruh Earning Before Tax (EBT) atau Laba Kotor terhadap Harga Saham.

3. Untuk Mengkaji dan menganalisis pengaruh Liabilitas terhadap Harga Saham.

4. Untuk Mengkaji dan menganalisis Pengaruh Modal (Equity) terhadap Harga Saham.

5. Untuk Mengkaji dan menganalisis Pengaruh Penjualan terhadap Harga Saham.

6. Untuk Mengkaji dan menganalisis Pengaruh Size (Total Aset) terhadap Harga Saham

Kajian Literatur

Pengungkapan

Pengungkapan (disclosure)

didefinisikan sebagai penyediaan sejumlah informasi yang dibutuhkan untuk pengoperasian secara optimal pasar modal yang efisien. Evan, membatasi pengertian pengungkapan hanya pada hal-hal yang menyangkut pelaporan keuangan.
Pernyataan manajemen dalam surat kabar atau media masa lain serta informasi di luar lingkup pelaporan keuangan tidak masuk dalam pengertian pengungkapan. Sementara itu, Wolk, Tearney, dan Dodd memasukkan pula statemen keuangan segmental dan statemen yang merefleksi perubahan harga sebagai bagian dari pengungkapan (Suwardjono, 2005). Dalam interpretasi yang lebih luas, pengungkapan terkait dengan informasi yang terdapat dalam laporan keuangan maupun informasi tambahan (supplementary communications) yang terdiri dari catatan kaki, informasi tentang kejadian setelah tanggal pelaporan, analisis manajemen tentang operasi perusahaan di masa yang mendatang, prakiraan keuangan dan operasi, serta informasi lainnya.

Laba Bersih (Net Profit)

Pada umumnya tujuan dari pengelolaan keuangan adalah memaksimumkan nilai perusahaan, yang salah satunya dapat dicapai dengan meningkatkan laba bersih perusahaan. Laba bersih merupakan kelebihan pendapatan yang dikeluarkan dalam proses menghasilkan pendapatan.

\section{Laba Kotor}

Laba sebelum Pajak adalah selisih pendapatan dengan harga pokok penjualan. Laba kotor setelah dikurang biaya operasional namun sebelum dihtung pajak.

Laba dapat dijadikan ukuran untuk menilai keberhasilan perusahaan. Pengukuran terhadap laba tidak akan memberikan informasi yang bermanfaat bila tidak menggambarkan sebab-sebab timbulnya laba. Sumber penyebab timbulnya laba memiliki peranan penting dalam menilai kemajuan perusahaan.

\section{Liabilitas}

Hutang adalah kewajiban perusahaan yang timbul karena tindakan atau transaksi-transaksi di masa lampau untuk memperoleh aktiva atau jasa, yang pelunasannya baru akan dilakukan di masa yang akan datang, baik dengan 
penyerahan uamg tunai, aktiva-aktiva tertentu lainnya, jasa maupun dengan menciptakan hutang baru. Hutang dapat menimbulkan kewajiban keuangan ataupun kewajiban pelaksanaan. Sebagai contoh, kewajiban keuangan misalnya hutang usaha, hutang pajak, hutang deviden, hutang bunga dan sebagainya, sedangkan kewajiban pelaksanaan, misalnya sewa yang diterima di muka, beban yang diterima di muka, uang garansi pembelian dari para pembeli.

Modal (Ekuitas)

Ekuitas adalah kepetingan residu dalam aset dari perusahaan setelah dikurangi semua liabilitas. Ekuitas sering mengacu kepada ekuitas pemegang saham, shareholders equity atau modal perseroan.

Size (Total Aset)

Aset adalah sumber daya dalam bentuk harta benda atau hak yang dikuasai oleh perusahaan.

Penjualan (Sale)

pengertian penjualan ialah sebuah transaksi dilakukan dua pihak atau lebih antara satu orang ke orang lain dengan pembayaran yang sah yang menghasilkan suatu pendapatan atau kita jabarkan lagi secara luas pengertian penjualan ialah sebuah aktivitas yang bertujuan untuk mencari pembeli / mempengaruhi konsumen agar terdapat suatu transaksi yang dilakukan oleh kedua pihak dengan alat pembayaran yang sah dan saling menguntungkan bagi kedua pihak tersebut.

\section{Harga Saham}

Menurut pasal 1 Undang-Undang Pasar Modal Nomor 8 Tahun 1995 mendefinisikan Bursa efek sebagai pihak yang menyelenggarakan dan menyediakan system dan/ atau sarana untuk mempertemukan penawaran jual dan beli efek pihak-pihak lain dengan tujuan memperdagangkan efek. Saham adalah tanda bukti memiliki perusahaan dimana pemiliknya disebut sebagai pemegang saham (shareholder atau stockholder) (Samsul, 2006). Bukti bahwa seseorang atau suatu pihak dapat dianggap sebagai pemegang saham adalah apabila mereka sudah tercatat sebagai pemegang saham dalam buku yang disebut Daftar Pemegang Saham (DPS). Bukti bahwa seseorang adalah pemegang saham juga dapat dilihat pada halaman belakang lembar saham apakah namanya sudah diregistrasi oleh perusahaan (emiten) atau belum.

Harga pasar (market price) adalah harga yang sedang berlaku di pasar. Nilai pasar saham adalah harga suatu saham pada pasar yang sedang berlangsung di bursa efek. Apabila bursa efek telah tutup maka harga pasar adalah harga penutupannya (clossing price). Untuk mendapatkan jumlah nilai pasar (market value) suatu saham yaitu dengan mengalikan harga pasar dengan jumlah saham yang dikeluarkan (Sunariyah, 2004). Biasanya pergerakan harga saham disajikan setiap hari, berdasarkan harga penutupan di bursa pada hari tersebut.

\section{METODE}

Jenis penelitian ini adalah metode deskriptif (survey) dengan desain penelitian kuantitatif, yaitu penelitian tidak hanya memberikan gambaran mengenai fenomena tetapi juga menerangkan, menguji hipotesis dan mendapatkan makna dari fakta yang ada.

Jenis dan sumber data yang digunakan dalam penelitian ini dapat dijelaskan sebagai berikut :

1. Jenis data yang digunakan adalah data sekunder karena berasal dari data yang telah mengalami proses pengolahan.

2. Data yang digunakan merupakan data kuantitatif dan data kualitatif. Data kuantitatif dinyatakan dalam angka-angka, menunjukkan nilai terhadap besaran atau variabel yang diwakilinya, sedangkan data kualitatif digunakan untuk memahami peristiwa dibalik data kuantitatif.

3. Jenis data yang digunakan dalam penelitian ini adalah berupa data sekunder, data mengenai perusahaan 
Pengaruh informasi akuntansi keuangan perusahaan terhadap harga saham pada perusahaanperusahaan industri perdagangan, jasa dan investasi yang terdaftar di bursa efek indonesia untuk tahun

industri perdagangan, jasa dan investasi yang telah listing di Bursa Efek Indonesia selama periode tahun 2007 - 2016. Data diperoleh dari Bursa Efek Indonesia.

4. Data bersifat time-series, yaitu data dari hasil pengamatan dalam suatu periode waktu tertentu, misalnya data harian, data bulanan atau data tahunan. Dalam penelitian ini runtun waktu atau time-series, data dari tahun 2007 - 2016.

Populasi yang digunakan dalam penelitian ini adalah perusahaan industri perdagangan, jasa dan investasi yang terdaftar di Bursa Efek Indonesia periode tahun 2007 - 2016.

Pengambilan sampel dalam penelitian ini dilakukan dengan menggunakan purposive sampling.

Metode purposive sampling adalah pengambilan sampel berdasarkan pertimbangan subjektif peneliti, dimana syarat dibuat sebagai kriteria yang harus dipenuhi oleh sampel (Algifari). Perusahaan yang diteliti adalah perusahaan industri perdagangan, jasa dan investasi periode tahun 2007 - 2016 dengan kriteria sebagai berikut:

1. Terdaftar di Bursa Efek Indonesia sebagai emiten selama jangka waktu 2007 - 2016.

2. Perusahaan tersebut memenuhi kelengkapan data selama periode penelitian.

Variabel yang diteliti dalam penelitian ini adalah

1. Net Profit (Laba Bersih) $=X_{1}$

2. Earning Before Tax (Laba Kotor) $=X_{2}$

3. Liabilitas $=X_{3}$

4. Modal (Equity) $=X_{4}$

5. Penjualan (Pendapatan $)=X_{5}$

6. Size $($ Total Aset $)=X_{6}$

7. Harga Saham $=Y$

\begin{tabular}{|l|l|l|l|}
\hline Variabel & Definisi & Pengukuran & Skala \\
\hline Net Profit & Laba akhir & selisih antara & Nomin \\
(Laba & setelah & pendapatan,ha & al \\
Bersih) & dikurangi & rga pokok & \\
& seluruh penjualan dan & \\
& biaya baik & beban yang & \\
& biaya & dikeluarkan & \\
& harga & dalam proses & \\
\hline
\end{tabular}
2008 hingga 2016 (Dini Onasis)

\begin{tabular}{|c|c|c|c|}
\hline & $\begin{array}{l}\text { Pokok } \\
\text { maupun } \\
\text { pajak }\end{array}$ & $\begin{array}{l}\text { menghasilkan } \\
\text { pendapatan } \\
\text { setelah } \\
\text { dikurangi } \\
\text { Pajak }\end{array}$ & \\
\hline $\begin{array}{l}\text { Earning } \\
\text { Before } \\
\text { Tax (Laba } \\
\text { Kotor) }\end{array}$ & $\begin{array}{l}\text { Laba } \\
\text { setelah } \\
\text { dikurangi } \\
\text { biaya } \\
\text { harga } \\
\text { Pokok } \\
\end{array}$ & $\begin{array}{l}\text { Laba setelah } \\
\text { dikurangi } \\
\text { biaya harga } \\
\text { Pokok } \\
\text { Penjualan }\end{array}$ & $\begin{array}{l}\text { Nomin } \\
\text { al }\end{array}$ \\
\hline Liabilitas & $\begin{array}{l}\text { kewajiban } \\
\text { perusahaan } \\
\text { yang } \\
\text { timbul } \\
\text { karena } \\
\text { tindakan } \\
\text { atau } \\
\text { transaksi- } \\
\text { transaksi } \\
\text { di masa } \\
\text { lampau } \\
\text { untuk } \\
\text { memperole } \\
\text { h aktiva } \\
\text { atau jasa, } \\
\text { yang } \\
\text { pelunasann } \\
\text { ya baru } \\
\text { akan } \\
\text { dilakukan } \\
\text { di masa } \\
\text { yang akan } \\
\text { datang, } \\
\text { baik } \\
\text { dengan } \\
\text { penyeraha } \\
\text { n uamg } \\
\text { tunai, } \\
\text { aktiva- } \\
\text { aktiva } \\
\text { tertentu } \\
\text { lainnya, } \\
\text { jasa } \\
\text { maupun } \\
\text { dengan } \\
\text { menciptak } \\
\text { an hutang } \\
\text { baru }\end{array}$ & $\begin{array}{l}\text { Total } \\
\text { Liabilitas } \\
\text { Liabilitas } \\
\text { Lancar } \\
\text { Liabilitas } \\
\text { jangka } \\
\text { Panjang }\end{array}$ & $\begin{array}{l}\text { Nomin } \\
\text { al }\end{array}$ \\
\hline $\begin{array}{l}\text { Modal } \\
\text { (Equity) }\end{array}$ & $\begin{array}{l}\text { Ekuitas } \\
\text { pemegang } \\
\text { saham, } \\
\text { shareholde } \\
\text { rs equity } \\
\text { atau modal } \\
\text { perseroan }\end{array}$ & $\begin{array}{l}\text { Kepetingan } \\
\text { residu dalam } \\
\text { aset dari } \\
\text { perusahaan } \\
\text { setelah } \\
\text { dikurangi } \\
\text { semua } \\
\text { liabilitas }\end{array}$ & $\begin{array}{l}\text { Nomin } \\
\text { al }\end{array}$ \\
\hline $\begin{array}{l}\text { Penjualan } \\
\text { (Pendapat } \\
\text { an) }\end{array}$ & $\begin{array}{l}\text { Transaksi } \\
\text { dilakukan } \\
\text { dua pihak }\end{array}$ & $\begin{array}{l}\text { Jumlah } \\
\text { Penjualan } \\
\text { satu tahun } \\
\end{array}$ & $\begin{array}{l}\text { Nomin } \\
\text { al }\end{array}$ \\
\hline
\end{tabular}




\begin{tabular}{|c|c|c|c|}
\hline & $\begin{array}{l}\text { atau lebih } \\
\text { antara satu } \\
\text { orang ke } \\
\text { orang lain } \\
\text { dengan } \\
\text { pembayara } \\
\text { n yang sah } \\
\text { yang } \\
\text { menghasil } \\
\text { kan suatu } \\
\text { pendapata } \\
\text { n }\end{array}$ & & \\
\hline $\begin{array}{l}\text { Size } \\
\text { (Total } \\
\text { Aset) }\end{array}$ & $\begin{array}{l}\text { Sumber } \\
\text { daya } \\
\text { dalam } \\
\text { bentuk } \\
\text { harta } \\
\text { benda atau } \\
\text { hak yang } \\
\text { dikuasai } \\
\text { oleh } \\
\text { perusahaan }\end{array}$ & $\begin{array}{l}\text { Total Aset = } \\
\text { Aset Lancar + } \\
\text { Aset Tidak } \\
\text { Lancar }\end{array}$ & $\begin{array}{l}\text { Nomin } \\
\text { al }\end{array}$ \\
\hline $\begin{array}{l}\text { Harga } \\
\text { Saham }\end{array}$ & $\begin{array}{l}\text { Saham } \\
\text { adalah } \\
\text { tanda bukti } \\
\text { memiliki } \\
\text { perusahaan } \\
\text { dimana } \\
\text { pemiliknya } \\
\text { disebut } \\
\text { sebagai } \\
\text { pemegang } \\
\text { saham } \\
\text { (sharehold } \\
\text { er atau } \\
\text { stockholde } \\
\text { r }\end{array}$ & Harag saham & $\begin{array}{l}\text { Nomin } \\
\text { al }\end{array}$ \\
\hline
\end{tabular}

Metode analisis yang digunakan adalah Regresi, Cross Section, Panel Data. Setelah data diperoleh selanjutnya dilakukan analisis dengan menggunakan analisis regresi linear berganda untuk mengetahui pengaruh variabel independen terhadap variabel dependen, dengan bantuan program pengolahan data statistik yaitu Statical Package for Social Science (SPSS). Untuk melihat kemampuan variabel independen dalam menerangkan variabel dependen dianalisis dari nilai koefisien determinasi ( $R$ square). Model analisis yang digunakan adalah:

$\mathrm{Y}=\mathrm{b}_{0}+\mathrm{b}_{1} X_{1}+\mathrm{b}_{2} X_{2}+\mathrm{b}_{3} X_{3}+\mathrm{b}_{4} X_{4}+\mathrm{b}_{5} X_{5}+\mathrm{b}_{6} X_{6}+\mathrm{e}$
Dimana:

Y= Harga Saham

$\mathrm{b}_{0}=$ Intercept point,

$\mathrm{b}_{1}-\mathrm{b}_{7}=$ Koefisien regresi,

$\mathrm{X}_{1}-\mathrm{X}_{6}=$ adalah Variabel independen yaitu,

$\mathrm{X}_{\mathrm{I}}=$ Net Profit (Laba Bersih),

$\mathrm{X}_{2}=$ Earning Before Tax (Laba Kotor),

$\mathrm{X}_{3}=$ Liabilitas,

$\mathrm{X}_{4}=$ Modal (Equity),

$\mathrm{X}_{5}=$ Penjualan (Pendapatan),

$\mathrm{X}_{6}=$ Size (Total Aset)

$\mathrm{e}=$ Kesalahan pengganggu .

\section{HASIL}

Penelitian menggunakan data sekunder pada perusahaan yang terdaftar pada perusahaan go publik yang tercatat di Bursa Efek Indonesia Periode 2008 -2016. Data yang digunakan adalah laporan keuangan tahunan dan data mengenai saham yang didapat dari Bursa Efek Indonesia untuk perusahaan yang terdaftar diperusahaan manufaktur basic industri, Terdapat 47 perusahaan yang dapat di teliti. Uji Asumsi Klasik

\section{Uji Normalitas Data}

Tujuan dari uji normalitas adalah untuk menguji dalam sebuah model regresi, variabel dependen dan variabel independen terdistribusi secara normal atau tidak. Pengujian normalitas data dalam penelitian ini dilakukan dengan menggunakan diagram distribusi normal dibawah ini :

Uji Normalitas

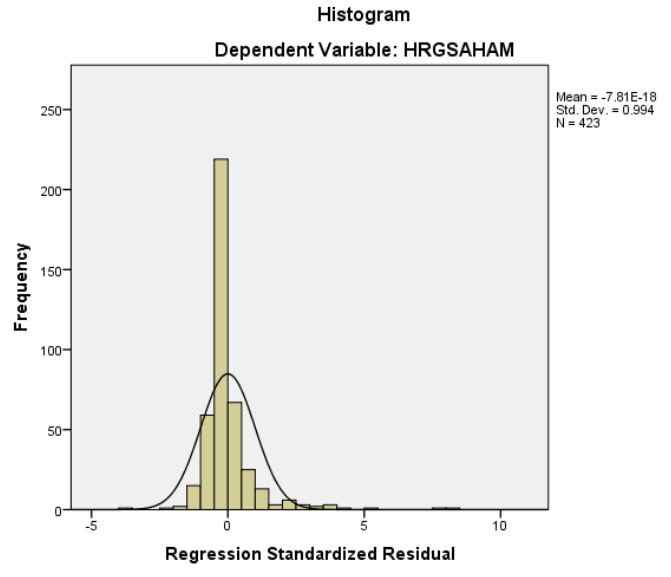

Dilihat diagram histogram, maka membentuk lengkung kurve normal maka 
residual dinyatakan normal dan asumsi normalitas terpenuhi. Jika kita lihat dari diagram disribusi normal diatas maka data penelitian ini mempunyai penyebaran data yang normal. Data penelitian yang memiliki penyebaran data yang normal maka alat uji yang digunakan dalam penelitian ini adalah alat uji statistik perametrik.

\section{Uji Multikolonieritas}

Uji Multikolonieritas digunakan untuk mengetahui ada atau tidaknya penyimpangan asumsi klasik multikolonieritas,yaitu adanya hubungan linear antar variabel independen dalam model regresi. Untuk menguji adanya multikolonieritas dapat dilihat melalui Variance Inflantion Factor (VIF) $<10$ dan tolerance $>0,10$. Hasil sebelumnya terdapat multikolenieritas pada Size sehingga Size dikeluarkan.

Hasil lanjutan uji multikolonieritas dijelaskan pada tabel berikut ini:

uji multikolonieritas

\begin{tabular}{|l|l|}
\hline \multicolumn{2}{|l|}{ Collinearity Statistics } \\
\hline Tolerance & VIF \\
\hline & \\
\hline .296 & 3.373 \\
\hline .148 & 6.769 \\
\hline .216 & 4.623 \\
\hline 141 & 7.068 \\
\hline .263 & 3.798 \\
\hline
\end{tabular}

Dari data dapat diketahui bahwa nilai Tolerance dari kelima variabel independen lebih dari 0,10 dan Variance Inflantion Factor(VIF) kurang dari 10, jadi dapat disimpulkan bahwa dalam model regresi tidak terjadi masalah multikolonieritas.

\section{Uji Autokorelasi}

Uji Autokorelasi digunakan untuk mengetahui ada atau tidaknya penyimpangan asumsi klasik autokorelasi, yaitu korelasi yang terjadi antara residual pada saat pengamatan dengan pengamatan lain pada model regresi. Model pengujian yang digunakan adalah Uji Durbin Watson.Berikut adalah rincian uji autokorelasi:

Uji Autokorelasi
Model Summary ${ }^{b}$

R Adjusted Std. Error of DurbinModelR Square R Square the Estimate Watson \begin{tabular}{lllll}
\hline 1 & $.743^{\mathrm{a}} .552$ & .547 & 2529.02692 & 1.945
\end{tabular}

Dari data di atas dapat dilihat bahwa nilai statistik Durbin Watson ( DW) sebagai hasil output dari SPSS adalah sebesar 1.945 Syarat tidak terjadi otokorelasi adalah $1<\mathrm{DW}<3$.

Angka DW pada penelitian ini menunjukkan nilai 1.945 , angka ini lebih besar dari pada 1 dan lebih kecil dari 3 . Karena DW berada diantara $1<2.037<3$ maka DW berada diantara dua angkat batasan Otokorelasi, maka dapat disimpulkan bahwa penilitian tidak mengalami Otokorelasi.

Uji Heteroskedastisitas

Uji heteroskedastisitas digunakan untuk mengetahui ada atau tidaknya penyimpangan asumsi klasik heteroskedastisitas, yaitu adanya ketidaksamaan varian dari residual untuk semua pengamatan pada model regresi. Untuk mendeteksi adanya heteroskedastisitas pada model yang akan diuji dalam penelitian ini dapat dilihat dari ada atau tidaknya pola tertentu pada garis Scatter Plot. Uji heteroskedastisitas dalam penelitian ini dapat dilihat dari gambar Scatter Plot berikut:

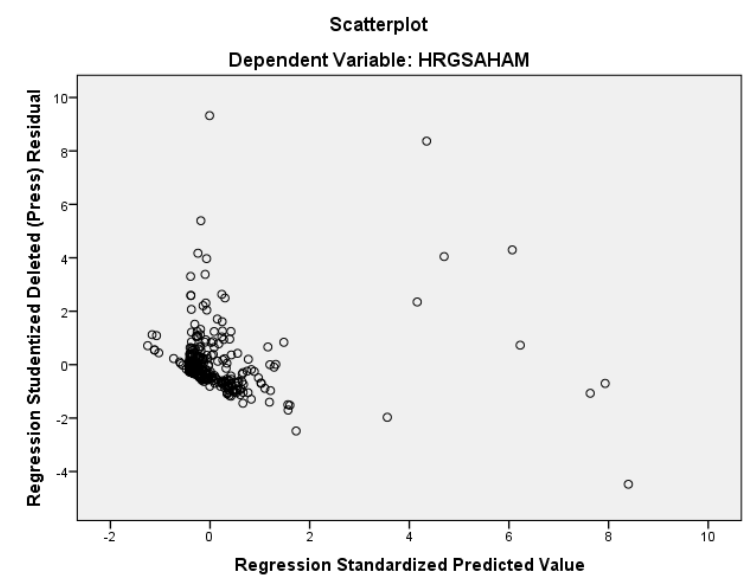

Dari grafik Scatter Plot diatas terlihat bahwa titik (data) menyebar dan tidak membentuk pola tertentu,serta tersebar baik . Sehingga dapat disimpulkan model regresi ini tidak terjadi heteroskedastisitas. 
Analisis Regresi

\begin{tabular}{|c|c|c|c|c|c|c|c|}
\hline \multicolumn{8}{|c|}{ Coefficients $^{\mathrm{a}}$} \\
\hline \multirow[b]{5}{*}{ Model } & \multicolumn{3}{|r|}{ Standardize } & \multirow[b]{5}{*}{$t$} & \multirow{3}{*}{\multicolumn{3}{|c|}{$\begin{array}{l}\text { Collinearity } \\
\text { Statistics }\end{array}$}} \\
\hline & \multirow{2}{*}{\multicolumn{3}{|c|}{ Unstandardized d }} & & & & \\
\hline & Coeffic & ients & & & & & \\
\hline & & & & & \multirow[b]{2}{*}{ Sig. } & \multicolumn{2}{|l|}{ Toleranc } \\
\hline & B & Error & Beta & & & & VIF \\
\hline \multirow[t]{2}{*}{1 (Constant) } & 674.71 & 146.68 & & 4.60 & .00 & & \\
\hline & & & & 0 & 0 & & \\
\hline \multirow{2}{*}{\begin{tabular}{|l} 
LIABILIT \\
II
\end{tabular}} & -.148 & .058 & \begin{tabular}{|l|}
-.153 \\
\end{tabular} & & .01 & .296 & 3.37 \\
\hline & & & & $\begin{array}{l}2.53 \\
9\end{array}$ & 1 & & 3 \\
\hline \multirow[t]{2}{*}{ MODAL } & .131 & .067 & .166 & 1.95 & .05 & .148 & 6.76 \\
\hline & & & & 1 & 2 & & \\
\hline \multirow[t]{2}{*}{ SALE } & .249 & .048 & .368 & 5.21 & .00 & .216 & 4.62 \\
\hline & & & & 9 & 0 & & h \\
\hline \multirow[t]{2}{*}{ EBT } & 1.758 & .428 & .358 & 4.10 & .00 & .141 & 7.06 \\
\hline & & & & & 0 & & 8 \\
\hline \multirow[t]{2}{*}{ PROFIT } & .061 & .361 & .011 & .169 & .86 & .263 & 3.79 \\
\hline & & & & & 6 & & \\
\hline
\end{tabular}

Dari data di atas dapat diperoleh model persamaan regresi linier berganda sebagai berikut :

Harga Saham $=a-b_{1}$ (Liabiliti) $+b_{2}$ (Modal) $+b_{3}($ Sale $)+b_{4}($ EBT $)+b_{5}$ (Profit) $+\mathrm{e}$

Hasilnya adalah sebagai berikut :

Harga Saham $=674.714-0.148$ (Liabiliti) + 0,131 (Modal) + 0, .249 (Sale) + 1.758 $($ EBT $)+0.061$ (Profit)

\section{Uji Hipotesis}

Uji T

1. Hipotesis pertama :

Berdasarkan uji t yang dimuat pada tabel diatas tertulis t hitungnya adalah 2.539 sedangkan $t$ tabelnya sebesar 1,973 berarti $t$ hitung $>\mathrm{t}$ tabel dengan tingkat signifikansi $0,011 / 2=0,0055$ dimana lebih kecil dari pada 0.025 , maka hipotesis diterima artinya variabel Liabiliti berpengaruh secara sgnifikan terhadap Harga Saham.

2. Hipotesis kedua :

Berdasarkan uji t yang dimuat pada tabel diatas tertulis t hitungnya adalah 1.951 sedangkan t tabelnya sebesar 1,973 berarti t hitung $<\mathrm{t}$ tabel dengan tingkat signifikansi $0,052 / 2=0,026$ dimana lebih besar dari pada 0.025 , maka hipotesis ditolak artinya variabel Modal tidak berpengaruh secara signifikan terhadap Harga Saham.

3. Hipotesis ketiga :

Berdasarkan uji t yang dimuat pada tabel diatas tertulis t hitungnya adalah 5.219 sedangkan t tabelnya sebesar 1,973 berarti $t$ hitung $>\mathrm{t}$ tabel dengan tingkat signifikansi $0,00 / 2=0$ dimana lebih kecil dari pada 0.025 , maka hipotesis diterima artinya Sale berpengaruh secara sgnifikan terhadap Harga Saham.

4. Hipotesis empat :

Berdasarkan uji t yang dimuat pada tabel di atas tertulis $t$ hitungnya adalah 4.104 sedangkan $t$ tabelnya sebesar 1,973 berarti $\mathrm{t}$ hitung $>\mathrm{t}$ tabel dengan tingkat signifikansi $0,00 / 2=0$ dimana lebih kecil dari pada 0.025 , maka hipotesis diterima artinya variabel EBT berpengaruh secara sgnifikan terhadap Harga Saham.

5. Hipotesis lima :

Berdasarkan uji t yang dimuat pada tabel di atas tertulis $\mathrm{t}$ hitungnya adalah 0.169 sedangkan $t$ tabelnya sebesar 1,973 berarti $\mathrm{t}$ hitung $<\mathrm{t}$ tabel dengan tingkat signifikansi $0,866 / 2=0.433$ dimana lebih besar dari pada 0.025, maka hipotesis ditolak artinya variabel Profit tidak berpengaruh secara sgnifikan terhadap Harga Saham.

Uji F

\begin{tabular}{ll}
$\mathrm{F}$ & Sig. \\
\hline 102.719 & $.000^{\mathrm{b}}$
\end{tabular}

Hipotesis 6 :

Berdasarkan hasil olahan SPSS yang ditunjuk pada table 5.6 diatas terlihat bahwa $\mathrm{F}$ hitungnya 102.719 sedangkan $\mathrm{F}$ table 2,23 dimana tingkat signifikansi pada 0,00 lebih kecil dibandingkan 0,05/2= 0.025 maka dapat disimpulkan bahwa Liabiliti, Modal, Sale, EBT, dan Profit secara bersama-sama berpengaruh secara sgnifikan terhadap Harga Saham.

Walaupun Liabiliti, Modal, Sale, EBT, dan Profit secara bersama-sama berpengaruh terhadap Harga Saham tetapi pengaruh lima faktor tersebut tidak mendominasi. Hal ini terlihat dari hasil uji determinasi pada table dibawah ini :

Uji Determinasi

Model Summary

\begin{tabular}{lllll} 
ModelR & $\begin{array}{l}\mathrm{R} \\
\text { Square }\end{array}$ & $\begin{array}{l}\text { Adjusted } \\
\text { Square }\end{array}$ & $\begin{array}{l}\text { R Std. Error of } \\
\text { Estimate }\end{array}$ & $\begin{array}{l}\text { the Durbin- } \\
\text { Watson }\end{array}$ \\
\hline 1 & $.743^{\mathrm{a}} .552$ & .547 & 2529.02692 & 1.945 \\
\hline
\end{tabular}

Berdasarkan hasil uji determinasi yang termuat pada tabel di atas terlihat bahwa 
kelima Variabel tersebut yaitu Liabiliti, Modal, Sale, EBT, dan Profit berpengaruh terhadap Harga Saham sebesar hanya 54,7 \% sementara sisanya lagi dipengaruhi oleh faktor lainnya yang tidak termasuk dalam penelitian ini, artinya pada kasus ini Koefisien Determinasi menunjukkan Variabel-variabel Liabiliti, Modal, Sale, EBT, dan Profit secara bersama-sama bisa menjelaskan perubahan yang terjadi pada Harga Saham Sebesar 54,7 \% yang ditunjukkan pada Adjusted R Square sebesar $54,7 \%$ sementara sisanya dapat dijelaskan oleh pengaruh lain yang tidak di teliti dipenelitian ini.

\section{PEMBAHASAN}

Penelitian ini merupakan penelitian yang dilakukan pada Informasi Akuntansi Keuangan Perusahaan terhadap Harga Saham, penelitian ini membawa dan menggunakan variable keuangan yaitu, Liabiliti, Modal, Sale, EBT, dan Profit dengan meneliti pada sector Industri Perdagangan, Jasa Dan Investasi Yang Terdaftar Di Bursa Efek Indonesia Tahun 2008 Hingga 2016.

Ringkasan hasil penelitian :

\begin{tabular}{|c|c|c|}
\hline 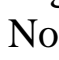 & Hipotesis & Hasil \\
\hline 1 & $\begin{array}{lr}\text { Liabiliti } & \text { berpengaruh } \\
\text { terhadap } & \text { Harga } \\
\text { Saham } & \end{array}$ & Berpengaruh \\
\hline & $\begin{array}{l}\text { Modal tidak } \\
\text { berpengaruh terhadap } \\
\text { Harga Saham }\end{array}$ & $\begin{array}{l}\text { Tidak } \\
\text { berpengaruh }\end{array}$ \\
\hline & $\begin{array}{lr}\text { Sale } & \text { berpengaruh } \\
\text { terhadap } & \text { Harga } \\
\text { Saham } & \end{array}$ & Berpengaruh \\
\hline & $\begin{array}{lr}\text { EBT } & \text { berpengaruh } \\
\text { terhadap } & \text { Harga } \\
\text { Saham } & \end{array}$ & Berpengaruh \\
\hline & $\begin{array}{l}\text { Profit tidak } \\
\text { berpengaruh terhadap } \\
\text { Harga Saham }\end{array}$ & $\begin{array}{l}\text { Tidak } \\
\text { berpengaruh }\end{array}$ \\
\hline
\end{tabular}

Hasil dari penelitian di atas di dapati bahwa Liabilitas berpengaruh pada Harga Saham pada perusahaan industri perdagangan, jasa dan investasi yang terdaftar di Bursa Efek Indonesia, hal ini sejalan dengan Teori Modigliani dan Miller yang menjelaskan bahwa dengan meningkatnya Hutang akan dapat menaikan laba karena terdapat pengurangan terhadap Pajak yang disebabkan oleh adanya biaya bunga pinjaman tersebut, dengan meningkatnya laba perusahaan maka hal ini mendapat respon yang positif dari publik sehingga dengan respon yang positif tersebut maka dapat mengakibatkan harga saham perusahaan dapat bergeser kearah naik.

Begitu juga sebaliknya jika proporsi liabilitas perusahaan sudah berada pada kondisi yang mengkuatirkan maka akan ada respon yang negative dan ketidakpercayaan publik atas beratnya beban yang ditanggung oleh perusahaan sehingga hal ini akan di tanggapi dengan menjual saham perusahaan tersebut yang dapat mengakibatkan harga saham bergeser turun.

Hasil dari penelitian diatas di dapati bahwa Modal tidak berpengaruh terhadap Harga Saham pada perusahaan industri perdagangan, jasa dan investasi yang terdaftar di Bursa Efek Indonesia, Hasil ini terlihat pada nilai signifikansi pengujian sebesar 0,052 diatas tingkat signifikansi 0,05 , sehingga variabel Modal tidak dapat dijadikan indikator dalam memprediksi harga saham.

Hasil dari penelitian diatas di dapati bahwa Sale berpengaruh terhadap Harga Saham pada perusahaan industri perdagangan, jasa dan investasi yang terdaftar di Bursa Efek Indonesia, Hasil ini terlihat pada nilai signifikansi pengujian sebesar 0,00 dibawah tingkat signifikansi 0,05 , sehingga variabel Sale dapat dijadikan indikator dalam memprediksi harga saham. Sebagaimana dijelaskan oleh Irham Fahmi bahwa investor menggunakan analisis rasio yang membawa unsur Sale dalam menilai kinerja keuangan suatu perusahaan untuk menemukan harga saham yang menarik dan menjadi perhatian bagi investor.

Variabel EBT menunjukkan pengaruh signifikan dan positif terhadap harga saham. Hasil ini terlihat pada nilai signifikansi pengujian sebesar 0,00 dibawah tingkat signifikansi 0,05 , sehingga variabel 
34 Pengaruh informasi akuntansi keuangan perusahaan terhadap harga saham pada perusahaanperusahaan industri perdagangan, jasa dan investasi yang terdaftar di bursa efek indonesia untuk tahun 2008 hingga 2016 (Dini Onasis)

EBT dapat dijadikan indikator dalam memprediksi harga saham. Investor dalam berinvestasi tidak hanya menilai menggunakan analisis teknikal yaitu analisis yang mendasarkan pada permintaan serta penawaran saham seperti kebijakan pemerintah tetapi juga kondisi fundamental perusahaan yang dapat di analisis pada kinerja keuangan yaitu Earning Before Ta atau laba sebelum pajak sebagai barometer dalam menentukan kinerja perusahaan sehingga dengan analisis fundamental perusahaan bagi investor sebagai acuan dalam berinvestasi yang nantinya akan mempengaruhi harga pasar saham perusahaan itu sendiri.

Namun Variabel Profit menunjukkan tidak berpengaruh terhadap harga saham. Hasil ini terlihat pada nilai signifikansi pengujian sebesar 0,866 diatas tingkat signifikansi 0,05 , sehingga variabel Profit tidak dapat dijadikan indikator dalam memprediksi harga saham, artinya publik tidak menjadikan Profit dalam memprediksi Harga Saham, naik turunnya Profit tidak mempengaruhi harga saham, hal ini dapat dikarenakan pada data yang ada terlihat bahwa $90 \%$ profit pada perusahaan Industri perdagangan, jasa dan investasi bersifat stabil dan tidak konstan, tentu hal ini bertentangan dengan teori namun jika Profit bersifat stabil maka hal ini merupakan suatu teori lain sebagai suatu pengecualian.

\section{SIMPULAN}

Hasil di dapati bahwa Liabilitas berpengaruh pada Harga Saham hal ini sejalan dengan Teori Modigliani dan Miller yang menjelaskan bahwa dengan meningkatnya Hutang akan dapat menaikan laba karena terdapat pengurangan terhadap Pajak yang disebabkan oleh adanya biaya bunga pinjaman tersebut, dengan meningkatnya laba perusahaan maka hal ini mendapat respon yang positif dari publik sehingga dengan respon yang positif tersebut maka dapat mengakibatkan harga saham perusahaan dapat bergeser kearah naik.

Begitu juga sebaliknya jika proporsi liabilitas perusahaan sudah berada pada kondisi yang mengkuatirkan maka akan ada respon yang negative dan ketidakpercayaan publik atas beratnya beban yang ditanggung oleh perusahaan sehingga hal ini akan di tanggapi dengan menjual saham perusahaan tersebut yang dapat mengakibatkan harga saham bergeser turun.

Hasil di dapati bahwa Modal tidak berpengaruh terhadap Harga Saham. Hasil di dapati bahwa Sale berpengaruh terhadap Harga Saham sehingga variabel Sale dapat dijadikan indikator dalam memprediksi harga saham. Sebagaimana dijelaskan oleh Toeri bahwa investor menggunakan analisis rasio yang membawa unsur Sale dalam menilai kinerja keuangan suatu perusahaan untuk menemukan harga saham yang menarik dan menjadi perhatian bagi investor.

Variabel EBT menunjukkan pengaruh signifikan dan positif terhadap harga saham. Investor dalam berinvestasi tidak hanya menilai menggunakan analisis teknikal yaitu analisis yang mendasarkan pada permintaan serta penawaran saham seperti kebijakan pemerintah tetapi juga kondisi fundamental perusahaan yang dapat di analisis pada kinerja keuangan yaitu Earning Before Tax atau laba sebelum pajak sebagai barometer dalam menentukan kinerja perusahaan sehingga dengan analisis fundamental perusahaan bagi investor sebagai acuan dalam berinvestasi yang nantinya akan mempengaruhi harga pasar saham perusahaan itu sendiri.

$$
\text { Namun Variabel Profit }
$$

menunjukkan tidak berpengaruh terhadap harga saham. Hal ini dapat dikarenakan pada data yang ada terlihat bahwa $90 \%$ profit pada perusahaan Industri perdagangan, jasa dan investasi bersifat stabil dan tidak konstan, tentu hal ini bertentangan dengan teori namun jika Profit bersifat stabil maka hal ini merupakan suatu teori lain sebagai suatu pengecualian.

Penelitian selanjutnya diharapkan dapat menggunakan alat analisis yang berbeda dengan penelitian sebelumnya. Dibutuhkan penelitian lanjutan untuk mencari pengaruh variable Liabiliti, Modal, 
Pengaruh informasi akuntansi keuangan perusahaan terhadap harga saham pada perusahaanperusahaan industri perdagangan, jasa dan investasi yang terdaftar di bursa efek indonesia untuk tahun

Sale, EBT, dan Profit dengan membawa variable intervening dan variable moderator untuk menemukan pengaruh terhadap Harga Saham.

\section{DAFTAR RUJUKAN}

Abarbanell, Jeffery S. \& Bushee, Brian J. (1998, January). Abnormal returns to a fundamental analysis strategy. The Accounting Review, 73 (1).

Irham Fahmi, 2014. Analisis Kinerja Keuangan. Alfabet. Bandung.

Febrianto, R., 2005, Tiga Angka Laba Akuntansi: Mana Yang Lebih Bermakna Bagi Investor?, Simposium Nasional Akuntansi 8 (Solo)

Daniati, Nina dan Suhairi. 2006. Pengaruh Kandungan Informasi Komponen Laporan Arus Kas dan laba bersih terhadap Expected Return Saham. Simposium Nasional Akuntansi (Padang).

Dini Onasis, 2016, Pengaruh Per Dan Ev/Ebitda Terhadap Harga Saham Perusahaan Pada Industri BarangBarang Konsumsi Di Bursa Efek Jakata, Jurnal Ilmiah Ekonomi dan Bisnis, Vol. 13 No.2 (2016).

Dini Onasis, 2017, Pengaruh Good Corporate Governance terhadap Manajemen Laba Perusahaan Industri Manufaktur Basic Industri yang Terdaftar di Bursa Efek Indonesia, Jurnal Ilmu Komputer dan Bisnis, Stimik Dharmapala Riau, Vol. 8, No. 1, 2017.

Lev, Thigarajan. (1993, autumn). Fundamental information analysis. Journal of Accounting Research, 31(2), 190-215
Palepu, Healy, Peek. (2014). Analisis dan Valuation Bisnis berbasis IFRS . ed 2. Salemba Empat. Jakarta.

Suwadjono. 2005. Teori Akuntansi: Perekayasaan Pelaporan Keuangan. Yogyakarta: BPFE UGM

Triyono dan Jogiyanto Hartono. 1998. Hubungan Kandungan Informasi Arus Kas, Komponen Arus Kas dan Laba Akuntansi dengan Harga atau Return Saham. Jurnal Riset Akuntansi Indonesia. Vol. 3. No. 1.

Widiastuti, Harjati. 2002. Pengaruh Luas Pengungkapan Sukarela dalam Laporan Tahunan terhadap Earning Response Coefficient (ERC). SNA V; Semarang, 5-6 September 2002. 